$\xi^{2}=$

\title{
Geomechanical characterization of mechanical properties and in-situ stresses for predicting wellbore stability of ATG-field, A case study: Niger delta petroleum province, Nigeria
}

\author{
Sebastian Abraham Sunu ${ }^{1 *}$, Adetola Sunday Oniku ${ }^{1}$, Osita Chukwudi Meludu ${ }^{1}$, Chukwuemeka Patrick Abbey ${ }^{2}$ \\ ${ }^{1}$ Physics Department, Modibbo Adama University of Technology, Yola, Adamawa State, Nigeria \\ ${ }^{2}$ American University of Nigeria, Yola, Nigeria \\ *Corresponding author E-mail: sunubazza@yahoo.com
}

\begin{abstract}
Well logs from ATG- field wells ATG-10 and ATG-11 were calibrated to develop Mechanical Earth Model (MEM) based on elastic parameter, failure parameters, in-situ stresses, pore pressure using well logs to predict wellbore failure. Poisson's ratio derived from compressional and shear velocities interval transit time and density logs (RHOB), showed that the values ranges from 0.17 to 0.48 and 0.09 to 0.49 , and the dynamic Young's Modulus derived from the Compressional and Shear velocity Logs, ranges from $6.0 \mathrm{GPa}$ to 7.8 $\mathrm{GPa}$ and 3.6 GPa to $6.6 \mathrm{GPa}$, the dynamic shear modulus derived from dynamic young's modulus and Poisson's ratio which ranges from $3.8 \mathrm{GPa}$ to $5.1 \mathrm{GPa}$ and $2.1 \mathrm{GPa}$ to $5.4 \mathrm{GPa}$, while the dynamic Bulk modulus ranges from $0.25 \mathrm{GPa}$ to $1.67 \mathrm{GPa}$ and $0.43 \mathrm{GPa}$ to 1.18 GPa for wells ATG-10 and ATG-11 respectively. The calibrated failure parameters or rock strengths derived from compressional velocity logs include: the internal friction angle $(\phi)$ from Plumb's correlation, these ranges from 20.869 o to $65.5 \mathrm{o}$ and $20.869 \mathrm{o}$ to $45.61 \mathrm{o}$, Unaxial compressive (UCS) strength ranges from 757.837 psi to 2505.836 psi and 4577.099 psi to 10512.876 psi, cohesion Strength (C) ranges from 205.697 psi to 355.308 psi and 70.652 psi to 390.32 psi and Tensile strength (To) varies from 17.141 psi to 29.609 psi and 5.885 psi to 32.527 psi for well ATG-10 and ATG-11 respectively. The elastic and rock strengths properties vary in a similar trend to the sonic logs as they are derived based on these values. These properties show increasing values with increasing depth, as a result of larger overburden stress, hence lower porosity or high compressional velocity of the formations. However, the elastic properties and formation strength may vary in different formations.
\end{abstract}

Keywords: ATG-Field; Mechanical Earth Model; Elastic Parameters; Rock Strength; In-Situ Stress.

\section{Introduction}

Maintaining a stable borehole is one of the major task and challenges encountered during exploration of hydrocarbon and it poses serious problems and challenges during exploration and production of hydrocarbon (Cheng, Tan \& Detournay, 2003). These problems and challenges are attributed to wellbore instability which is one of the reason for borehole failure and collapse (Zhang, 2013; Bozorgi, Javani, \& Rastegarnia, 2016), and since it has been included in the planning stage during development of a borehole. In Niger Delta petroleum province, common drilling problems encountered includes water coning, wellbore instability, sand production, wax deposition, and high gas/oil ratios (Kulke, 1995). Accurate wellbore stability analysis and understanding of local geomechanics can prevent many problems, such as borehole washouts, breakout, collapse, stuck pipes and drill bits, losses of drilling fluid and fluid influx (kick). It is estimated that the overall drilling costs increase by at least $10 \%$ due to wellbore instability issues (Aadnøy, 2003). Instability of wellbore also increases the drilling time, cost of drilling, and may lead to loss of the well and well bore abandonment before it reaches its objective (Luo et al., 2012). Therefore, wellbore stability analysis is of paramount importance in the oil and gas drilling. Geomechanical analyses are employed to generate data for the design of a stable wellbore. During circulation, Drilling Fluids (mud fluids) is being circulated and invade the stable formations which lead to reorientation of in-situ stress and concentration of stresses around wellbore wall, thus creating differential pressure between the wellbore and far field stresses that could exceed rock strengths which may cause formation or borehole failure (Moos, 2006; Denney, 2011). This incident is responsible for several changes that can result in wellbore instability, casing collapse, perforation failure, poor hydraulic propagation and initiation, other problems are due to reservoir stress changes occurring during production such as reservoir compaction, surface subsidence, formation fracturing, casing deformation and failure, sanding, reactivation of fault and bedding parallel slip (TLE, 2007). Ending wellbore instability begins with construction of mechanical earth model (MEM) and failure criterion analysis.

The mechanical earth model (MEM) is a numerical representation of the state of stress and rock mechanical properties rock strengths and pore pressure for a specific stratigraphic section in a field (Plumb et al., 2000). It is based on the concepts of stress and strain, which are related to the simple Hook's law. Mechanical earth model (MEM) combines geomechanical properties such as in-situ stress states, Pois- 
son's Ratio, pore pressure, Young's Modulus, shear modulus, bulk modulus and rock strengths parameters or failure parameters such as the unconfined compressive strength (UCS) and angle of internal friction $(\Phi)$, cohesion strength $(C)$, and tensile strength $\left(\mathrm{T}_{0}\right)$ of sedimentary rocks (Iqbal, Ahmad, \& Abd Kadir, 2017). These key parameters needed to address a range of geomechanical problems ranging from limiting wellbore instabilities during drilling (Moos et al., 2003), to assessing sanding potential and quantitatively constraining stress magnitudes using observations of wellbore failure (Zoback et al., 2003).

When the formation rock is subjected to sufficiently large stresses, a kind of failure occur either shear failure or tensile failure. The most common failure criteria are Mohr-Coulomb and Mogi-Coulomb. In this study, firstly, mechanical earth model (MEM) will be constructed using the existing relevant logs, data from the offset well describing the formation mechanical properties pore pressure, stress magnitudes from two offshore wells of ATG field, Niger Delta, and then the wellbore instability are analyzed based upon the developed model and the Mohr-Coulomb failure criterion.

\section{Geology of Niger delta}

The Niger Delta is termed one of the most potential hydrocarbon producing basins in the world and is also one of the largest sub-aerial basins in Africa is found in the Gulf of Guinea on the west coast of Central Africa extends throughout the Niger Delta Province (Klett, et al.,1997). It is located at latitudes $4^{0} 49^{\prime} \mathrm{N}$ and longitude $6^{0} 0^{\prime} \mathrm{E}$ at the south-southern part of Nigeria (Corredor, Lessenger, \& Capentino, 2005). It is bounded in the south by the Gulf of Guinea and in the North by older (Cretaceous) tectonic elements which include the Anambra Basin, Abakaliki uplift and the Afikpo syncline. In the east and west respectively, the Cameroon volcanic line and the Dahomey Basin mark the bounds of the Delta, Fig.1. The Cenozoic Niger Delta is situated at the intersection of the Benue trough and the South Atlantic Ocean where a triple junction developed during the separation of South America from Africa (Doust, \& Omatsola, 1990). The delta is considered one of the most prolific hydrocarbon provinces in the world, and recent giant oil discoveries in the deep-water areas suggest that this region will remain a focus of exploration activities (Doust, \& Omatsola,1990) having a sub-aerial section of about $75,000 \mathrm{~km}^{2}$, area measuring about $300,000 \mathrm{~km}^{2}$, and with sediment thickness of about $500,000 \mathrm{~km}^{3}$. The thickness of the sediments varies between 9 to $12 \mathrm{~km}$. Large-scale tectonics of the area must have resulted to different complexities in the geologic formation (Tuttle, Charpentier, \& Brownfield, 1999).

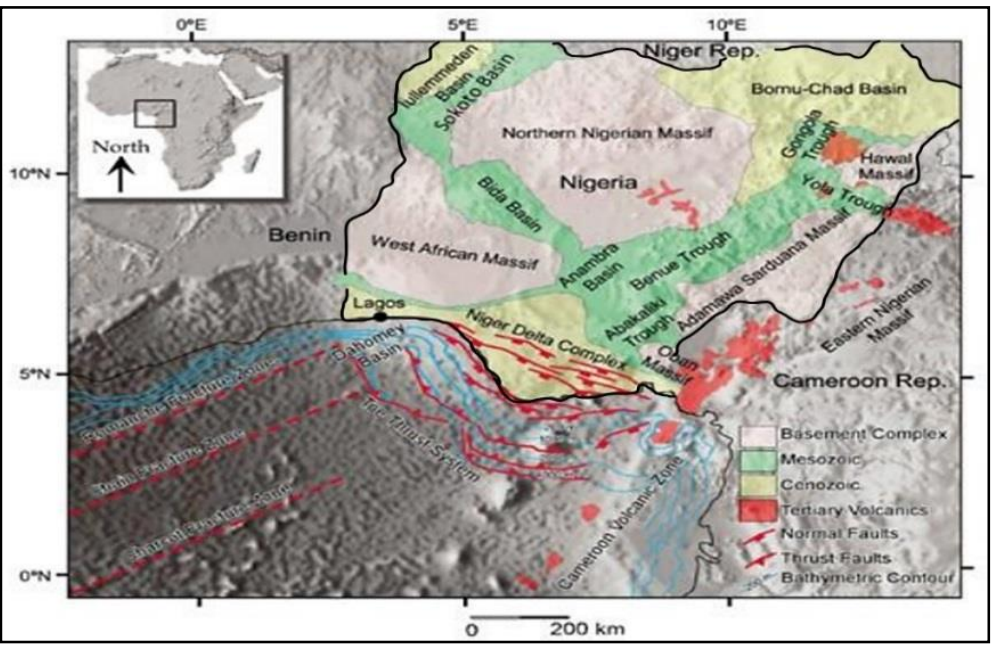

Fig. 1: Sedimentary Basins in Nigeria Shows the Niger Delta Province in the Gulf Guinea (Corredor Et., Al. 2005)

The studied area lies within depobelt offshore Niger Delta as shown in Fig 2. The studied field, ATG field is located offshore Niger Delta with an area of $52 \mathrm{~km}^{2}$ Fig. 3. The Niger Delta is a wave-dominated delta and is composed of an overall regressive clastic sequence which reaches a maximum thickness of about $12 \mathrm{~km}$ in the basin center. The Delta's sediments show an upward transition from marine pro-delta shales (Akata Formation) through a paralic interval (Agbada Formation) to a continental sequence (Benin Formation). These three sedimentary environments, typical of most deltaic environments extend across the whole delta and ranges in age from Early Tertiary to Recent. The offshore Niger Delta has the characteristic shelf slope break of growth fault modified ramp margins (Kaplan, Lusser, \& Norton, 1994).

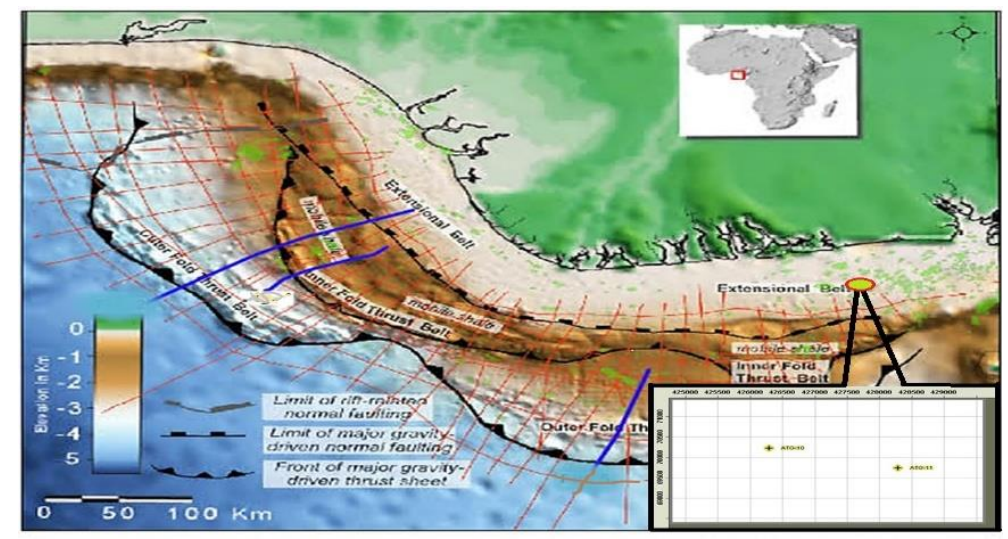

Fig. 2: High-Resolution Bathymetric Image of the Niger Delta Shows the Study Field and Main Structural Domains. from Corredor Et Al., (2005). 


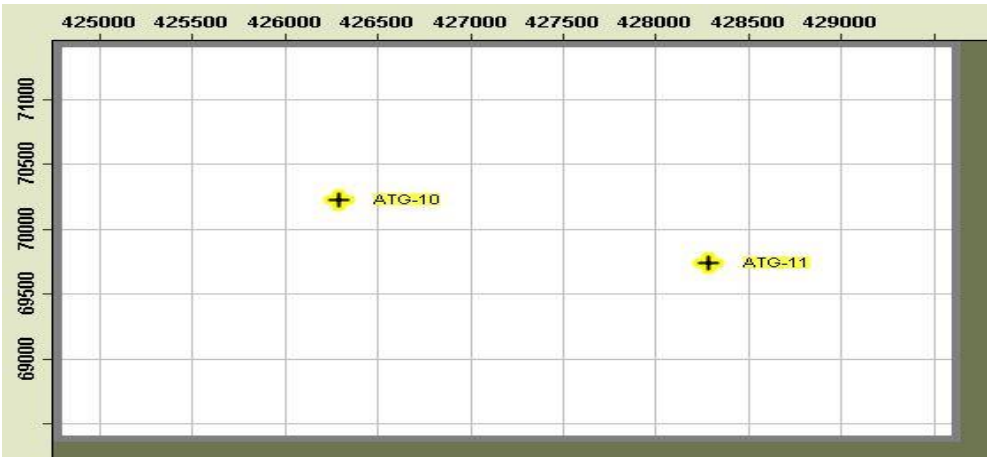

Fig. 3: Position and Location of ATG-10 and ATG-11 Wells (Ikon Science Rokdoc 6.1.4.1089).

\section{Stratigraphy and sedimentology of the Niger delta}

The stratigraphy and sedimentology of the Niger Delta, like other major deltas, is a function of the rate of sediment supply and basin tectonics. The interplay of these two factors as it relates to the Niger Delta stratigraphy, sedimentology, and structure have extensively discussed by (Short \& Stauble, 1967; Weber \& Daukoru, 1975; Doust \& Omatsola, 1990). Three major depositional cycles have been documented in the Basin (Short \& Stauble, 1967). Firstly, during the Early Cretaceous, a marine incursion covered the whole basin, and was terminated by weak folding in the Santonian. Secondly, the depositional cycle that created the proto-Niger delta during the Late Cretaceous terminated in a major Palaeocene marine transgression. The third depositional cycle has been ongoing since the Eocene, and is responsible for the southward growth of the main Niger Delta. The Cenozoic strata in the Niger Delta area comprise three main formations (Fig. 4). The base sequence, the Akata Formation, is up to $7000 \mathrm{~m}$ thick in the central part of the basin, and is a delta-front, deep marine deposit that mainly consists of a thick marine shale and clay with a rather silty base. It contains thin sand bodies of continental slope, channel-fill, and turbiditic origin. The shale forms diapirs offshore that are considered to be Palaeocene to Holocene in age (Doust \& Omatsola, 1990).

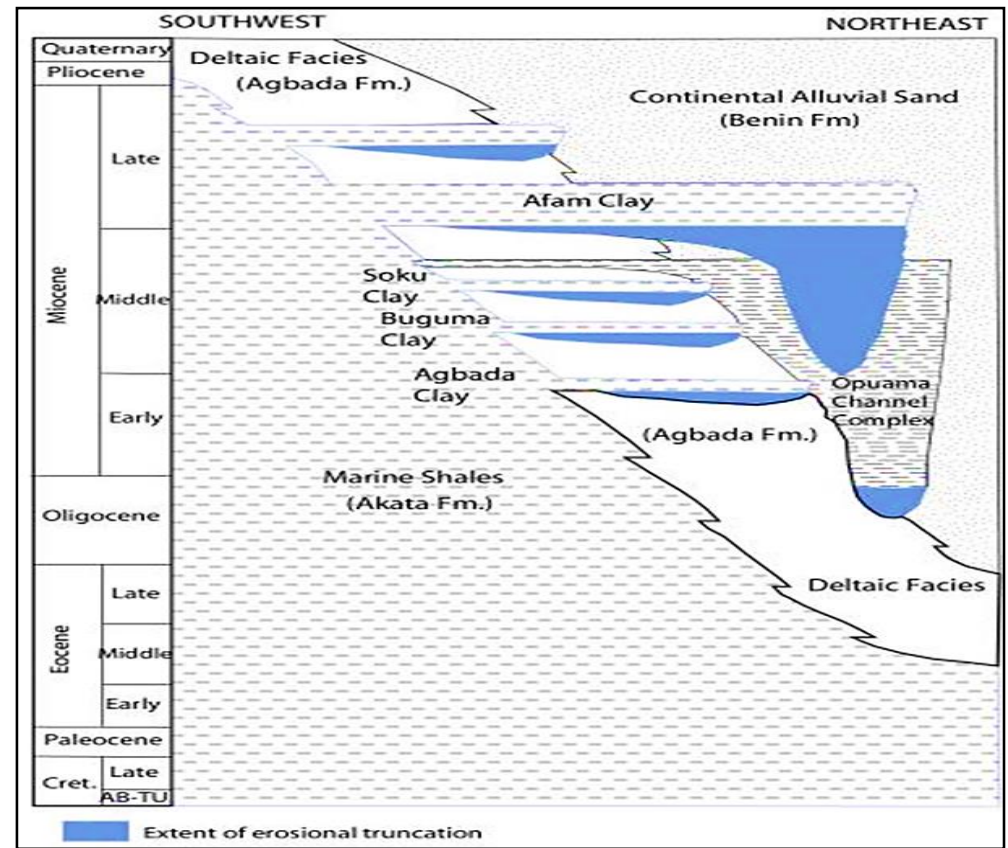

Fig. 4: Stratigraphic Column Shows the Three Formations of the Niger Delta (Tuttle Et., Al, 1999).

The Akata Formation is organic-rich and is generally accepted to be the main source rock in the Niger Delta area. Overlying the Akata Formation is a paralic sequence of up to $3000 \mathrm{~m}$ thickness, the Agbada Formation, which comprises intercalated shallow marine fluvial sands, silts and clays (Fig 5). These are delta front, delta topset, fluvio-deltaic deposits, ranging in age from Eocene to Pleistocene, and contain both reservoir and caprocks (Doust \& Omatsola, 1990). Though still quite controversial, (Short \& Stauble, 1967; Frankl \& Cordry, 1967; Lambert-Aikhionbare \& Ibe, 1984) have all suggested that the Agbada Formation may contain source rocks. The criteria for delineating the top and bottom of the Agbada Formation can be ambiguous and in practice vary from one company to another. Doust \& Omatsola (1990) suggested the practice of picking the top on wireline logs as the base of fresh water invasion, and the bottom corresponding to the onset of hard overpressure during drilling. Using cuttings from wells, Doust \& Omatsola (1990) pointed out that the Agbada Formation is sandier in the upper section than the lower section, may be consolidated to unconsolidated, and is generally poorly sorted with lignite streaks, shell fragments, and glauconite. The topmost sequence of massive non-marine sand is the Benin Formation. In the central part of the basin, it has a maximum thickness of about $2100 \mathrm{~m}$, and thins seawards to disappear near the shelf edge. The oldest sediments of the Benin Formation are thought to be Oligocene in age, and generally lack fauna (Doust \& Omatsola, 1990). As pointed out by Doust \& Omatsola (1990), these alluvial, coastal plain deposits contain insignificant quantities of hydrocarbon, but are of great hydrogeological interest. 


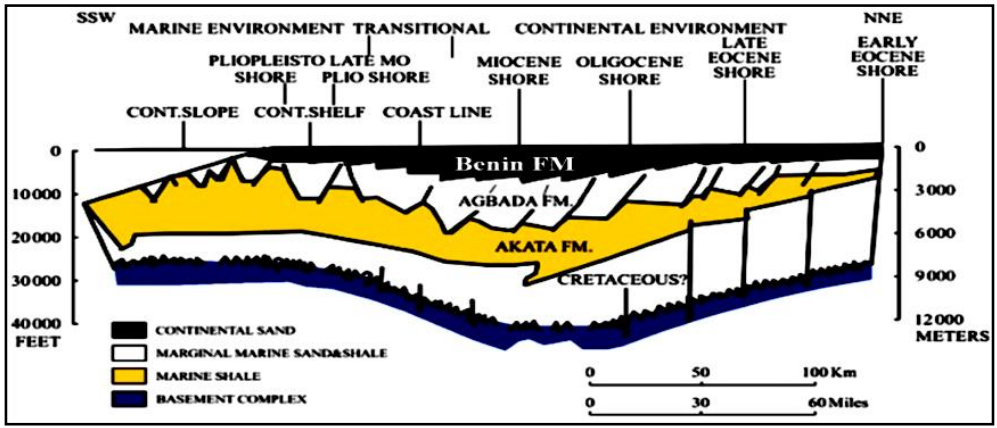

Fig. 5: Lithostratigraphic Sequence of the Niger Delta Offlap Cycles Shows the Three Distinct Lithologic Units: Akata, Agbada and Benin Formations (Doust, Omatsola, 1990)

\section{Materials and methods}

Data utilized for this study are well logs which include sonic, Density, Gamma ray, caliper neutron porosity and resistivity logs from two wells coded as ATG-10 and ATG-11 of ATG field for propriety reasons. These well logs are in LAS file format. The data analysis tools used in this study are Rock physics interpretational software Ikon science RokDoc for log conditioning and quality check. The well Logs data used to support the findings of this study have not been made available and the exact location of the wells could not be disclosed because of the existing Laws within the Oil Companies in Nigeria. However data may be made available upon application through the department of petroleum resources (DPR) Nigeria.

Mechanical Earth model (MEM) is an explicit description of the mechanical properties of the reservoir and overburden formations, and this includes; elastic properties, rock strength, pore pressure and the state of in situ stresses.

Dynamic elastic rock properties including the Young's modulus $\left(E_{\mathrm{dyn}}\right)$ and Poisson's ratio $\left(\vartheta_{\mathrm{dyn}}\right)$ are calculated in relation with the rock density $(\rho)$ and compression and shear wave velocity, $\mathrm{Vp}$ and $\mathrm{Vs}$, (inverse of compression and shear transit time DT and DTS from sonic $\log$ ) as below:

$$
\begin{aligned}
& E_{d y n}=\frac{\rho V_{s}^{2}\left(3 V_{p}^{2}-4 V_{s}^{2}\right)}{\left(V_{p}^{2}-V_{s}^{2}\right)} \\
& \vartheta_{d y n}=\frac{\left(v_{p}^{2}-2 V_{s}^{2}\right)}{2\left(v_{p}^{2}-V_{s}^{2}\right)}
\end{aligned}
$$

The dynamic properties representing log acquired data are converted to the static rock properties in static conditions Static young's modulus was calculate using the equation 3 , Wang (2000).

$$
\mathrm{E}_{\text {stat }}=0.4145 \mathrm{E}_{\mathrm{dyn}}-1.0593
$$

The shear modulus $(\mathrm{G})$ which is the ratio of the shear stress to the shear strain was estimated from static young's modulus and static poisons ratio expressed as:

$$
\mathrm{G}=\frac{\mathrm{E}_{\text {stat }}}{2\left(1+\vartheta_{\text {stat }}\right)}
$$

The bulk modulus (K) was computed from the static young's modulus and static Poisson's ratio expressed as:

$$
\mathrm{K}=\frac{\mathrm{E}_{\text {stat }}}{3\left(1-2 \vartheta_{\text {stat }}\right)}
$$

The Internal friction angle $(\phi)$ used for this study was calculated from linear equation Friction angle (FANG) can be estimated using Plumb's (1994) correlation in relation to the formation porosity and volume of the clay (Vclay):

$$
\phi=26.5-37.4\left(1-\mathrm{NPHI}-\mathrm{V}_{\mathrm{sh}}\right)+62.1\left(1-\mathrm{NPHI}-\mathrm{V}_{\mathrm{sh}}\right)^{2}
$$

Where, $\phi$ is the Internal friction angle (rad.), NPHI is the Neutron porosity $\log$ (fract.), $V_{s h}$ is the volume of shale calculated from equation 7 given as:

$$
V_{s h}=\frac{G R(\log )-G R(\min )}{G R(\max )-G R(\min )}
$$

Cohesion strength $\left(S_{O}\right)$ was calculated from the following empirical relation using the compressional velocity (Vp) log as follows:

$$
S_{O}=\frac{5\left(V_{P}-1\right)}{\sqrt{V_{P}}}
$$

The uniaxial compressive strength was determined from inherent cohesion strength and the internal friction angle $\phi$ (Lianyang, \& Radha, 2010) given as:

$$
U C S=C_{O}=\frac{2 S_{O} \cos \phi}{1-\sin \phi}
$$


Where,

$C_{O}=2 S_{O} \tan \beta$

$C_{O}$ is the uniaxial Compressive Strength, $\beta$ is the orientation of the failure plane, $S_{0}$ is the cohesive strength,

Where, $\tan ^{2} \beta=\frac{1+\sin \phi}{1-\sin \phi}$

Tensile strength: The tensile strength of the rocks is considered 1/10th of the UCS.

The overburden stress $\left(\sigma_{\mathrm{v}}\right)$ is the integration of rock density to the depth of interest. The density log is used across the available interval, (Bell, 2002) given as:

$$
\sigma_{v}=g \int_{0}^{z} \rho(z) d z
$$

Where, $\sigma_{\mathrm{v}}$ is the overburden stress, $\rho$ is the density, $\mathrm{g}$ is the acceleration due to gravity $\left(9.8 \mathrm{~m} / \mathrm{s}^{2}\right)$, and $\mathrm{Z}$ is the depth below mudline.

To obtain a continuous profile for pore pressure different correlations are used. Bower's Model utilized the Compressional velocity $\left(\mathrm{V}_{\mathrm{p}}\right)$ $\log$, where the relationship between the effective stress and velocity in the hydrostatic pressure (Bowers, 1995) and have a power relation in the loading stage of the form:

$$
V_{p}=V_{m l}+A \sigma_{e}^{B}
$$

Where, $\sigma=\left(\frac{V_{p}-V_{m l}}{A}\right)^{\frac{1}{B}}$

$\mathrm{Vp}$ is the compressional velocity, $\sigma_{\mathrm{e}}$ is the effective stress, $\mathrm{V}_{\mathrm{ml}}$ is the velocity of unconsolidated fluid saturated sediments $\mathrm{V}_{\mathrm{ml}} \sim 5000 \mathrm{ft} / \mathrm{s}$. $\mathrm{A}$ and $\mathrm{B}$ are constants which describe the variation in velocity with increasing differential stress. Using equations bowers pore pressure is expressed as:

$P_{p}=\sigma_{v}-\left(\frac{V_{p}-V_{m l}}{A}\right)^{\frac{1}{B}}$

The magnitude of Minimum horizontal stress and Maximum horizontal values can be calculated from poro-elastic equations below: Integrating the density in equation (11) log will give the vertical stress and is therefore; $\sigma_{v}=\sigma_{1}$

$S_{H}=\frac{\vartheta}{1-\vartheta}\left(\sigma_{\mathrm{v}}-\alpha \mathrm{P}_{\mathrm{P}}\right)+\alpha \mathrm{P}_{\mathrm{P}}+\frac{\mathrm{E}_{\mathrm{S}}}{1-\vartheta^{2}}\left(\varepsilon_{\mathrm{y}}+\vartheta \varepsilon_{\mathrm{x}}\right)=\sigma_{2}(15) \mathrm{S}_{\mathrm{h}}=\frac{\vartheta}{1-\vartheta}\left(\sigma_{\mathrm{v}}-\alpha \mathrm{P}_{\mathrm{P}}\right)+\alpha \mathrm{P}_{\mathrm{P}}+\frac{\mathrm{E}_{\mathrm{S}}}{1-\vartheta^{2}}\left(\varepsilon_{\mathrm{x}}+\vartheta \varepsilon_{\mathrm{y}}\right)=\sigma_{3}$

Where, $\varepsilon_{\mathrm{y}}=\frac{\sigma_{\mathrm{v}} \times \vartheta}{\mathrm{E}_{\mathrm{S}}} \times\left(1-\frac{\vartheta^{2}}{1-\vartheta}\right)$

$\varepsilon_{\mathrm{x}}=\frac{\sigma_{\mathrm{v}} \times \vartheta}{\mathrm{E}_{\mathrm{S}}} \times\left(\frac{1}{1-\vartheta}-1\right)$

Where the overburden pressure $\sigma_{\mathrm{v}}$, equation 16 gives the vertical stress. Where, $\mathrm{S}_{\mathrm{H}}$ is the Maximum horizontal, $\mathrm{S}_{\mathrm{h}}$ is the Minimum horizontal stress, Es is the static Young's modulus, (GPa), $\sigma_{v}$ is the vertical in-situ stress (overburden pressure) (psi), $\vartheta$ is the Poisson's ratio (dimensionless), $\mathrm{Pp}=$ pore pressure (psi), $\alpha$ is the Biot's coefficient (conventionally $\alpha=1$ ) and $\varepsilon_{\mathrm{y}}$ and $\varepsilon_{\mathrm{x}}$ are strain in $\mathrm{S}_{\mathrm{H}}$ and $\mathrm{S}_{\mathrm{h}}$ directions as given by Equations (17) and (18), respectively (Kidambi \& Kumar, 2016).

The failure criterion adopted for this study is the Mohr- Coulomb failure criterion which expressed the normal $\sigma_{\mathrm{n}}$ and shear $\tau$ stresses are expressed in terms of maximum and minimum principal stresses in Equations (19) and (20) (Jaeger Cook, \& Zimmerman, 2007).

$\sigma_{\mathrm{n}}=\frac{\sigma_{1}+\sigma_{3}}{2}+\frac{\sigma_{1}-\sigma_{3}}{2} \sin \phi$

And,

$\tau=\frac{\sigma_{1}-\sigma_{3}}{2} \cos \phi$

For a well borehole, the linear elastic model can be described as below (Lianyang \& Zhang 2010; Aadnøy \& Looyeh, 2011):

$\tau=S_{O}+\sigma_{n} \mu_{i}$

$\tau=\mathrm{S}_{\mathrm{O}}+\sigma_{\mathrm{n}} \tan \phi$

Where, $\mu_{\mathrm{i}}=\tan \phi=\frac{1+\sin \phi}{1-\sin \phi}$

Where, $\mu_{\mathrm{i}}$ is the Internal friction coefficient $\tau$ is the shear stress (Psi), $\mathrm{S}_{\mathrm{O}}$ is the cohesion strength (psi), $\sigma_{\mathrm{n}}$ is the effective normal stress (psi), $\phi$ is the internal friction angle. The numerical solution for the Mohr-Coulomb failure criterion is expressed in equation (24) (Islam et a,1. 2010).

$\mathrm{F}=\mathrm{S}_{\mathrm{O}} \times \cos \phi+\sin \phi\left(\sigma_{\mathrm{n}}-\mathrm{P}_{\mathrm{P}}\right)-\tau$ 
Where, $F$ is the failure criterion (psi), $P_{\mathrm{P}}$ is the Pore pressure (psi) $\mathrm{S}_{\mathrm{O}}$ is the cohesion strength (psi) $\tau=$ shear stress (psi), $\phi=$ internal frictional angle (Degrees), $\sigma_{\mathrm{n}}$ is thenormal stress (psi)

Compressional failure occurs when $\mathrm{F} \leq 0$ (less than or equal to zero).

\section{Results and discussions}

Geomechanical characterization and state of in-situ stress were characterized using two wells namely ATG-10 and ATG-11 obtained from ATG Field offshore Niger Delta. The data contains Gamma Ray, Resistivity compressional and shear velocity (Vp and Vs) Caliper, Density (RHOB) Neutron porosity logs fig. 6 \& . The data analysis tool used in this study is Rock physics software Ikon RokDoc for log conditioning, lithology, volume of shale, elastic properties, pore pressure and wellbore stresses were characterized for wellbore stability

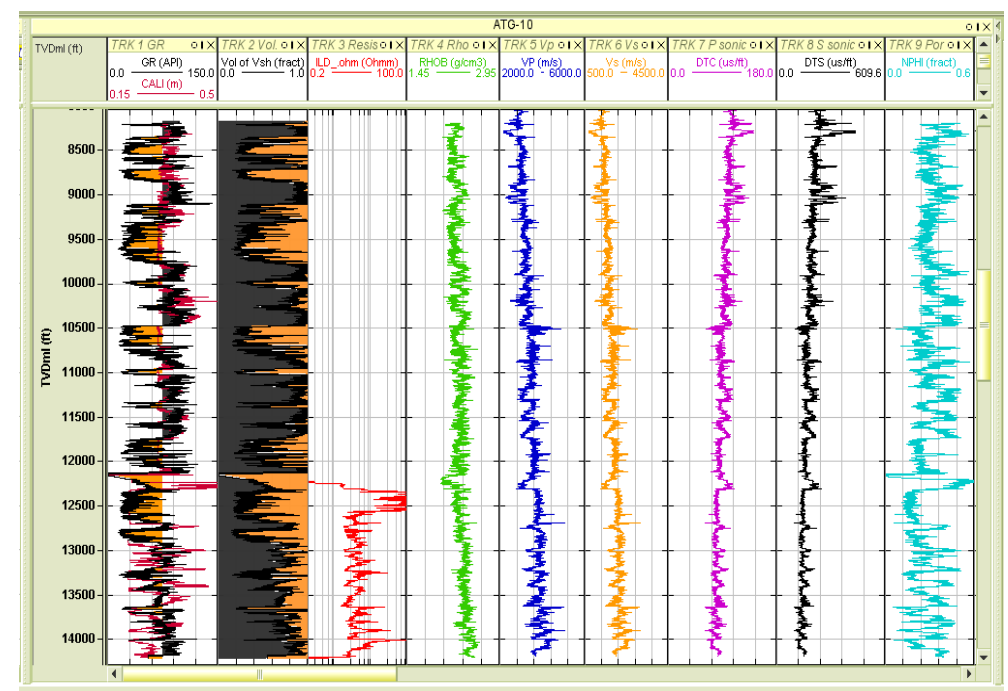

Fig. 6: Key Wireline Logs Lithology and Volume of Shale for Well ATG-10.

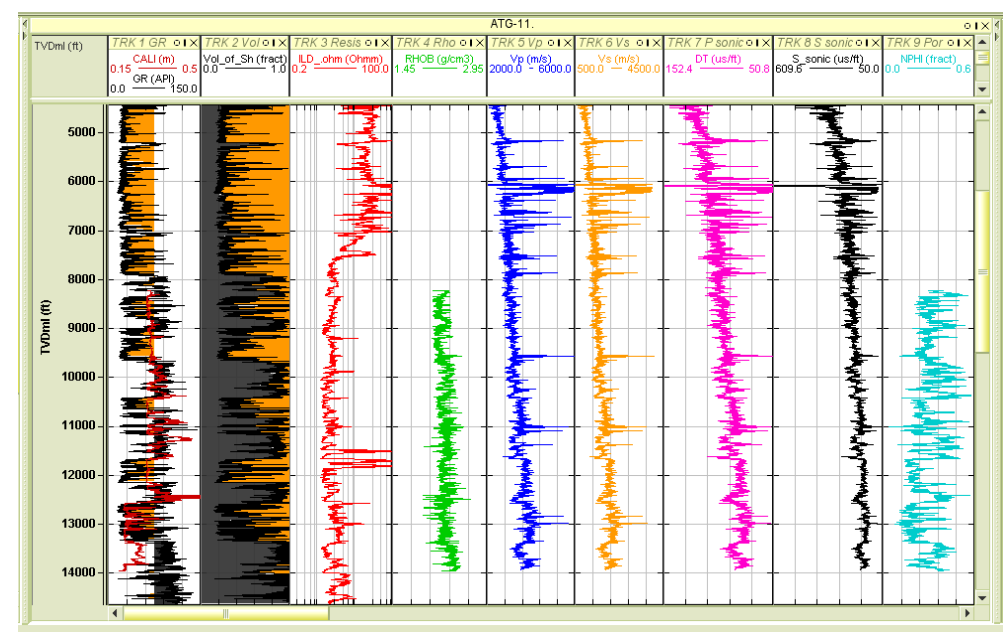

Fig. 7: Key Wireline Logs Lithology and Volume of Shale for Well ATG-11.

Results of Figures 8 and 9 are 1D geomechanical Earth model (MEM) analysis which shows the different value of elastic properties and rock strengths or failure parameters derived from empirical relations summarized in tables 1 and 2 for wells ATG-10 and ATG-11 respectively, the depth range corresponds to the interbeded sand and shales of the Agbada formation of ATG-field in the shallow offshore Niger Delta.

Track 1 shows the Gamma Ray log used in discriminating shale and sand interval (Lithology), and Track 2 shows volumetric fraction of clay (volume of shale), Track 3 is the caliper log indicating hole size, Track 4 shows the Poisson's ratio represents the formation strength derived from compressional and shear velocities interval transit time and density logs (RHOB), the Poisson's ratio values ranges from 0.17 to 0.48 and 0.09 to 0.49 , Track 5 is the dynamic Young's Modulus derived from the Compressional and Shear velocity Logs, which show the stiffness of the formation and ranges from $6.0 \mathrm{GPa}$ to $7.8 \mathrm{GPa}$ and $3.6 \mathrm{GPa}$ to $6.6 \mathrm{GPa}$, Track 6 is the dynamic shear modulus derived from dynamic young's modulus and Poisson's ratio which ranges from $3.8 \mathrm{GPa}$ to $5.1 \mathrm{GPa}$ and $2.1 \mathrm{GPa}$ to $5.4 \mathrm{GPa}$, Track 7 is the dynamic Bulk modulus which ranges from $0.25 \mathrm{GPa}$ to $1.67 \mathrm{GPa}$ and $0.43 \mathrm{GPa}$ to $1.18 \mathrm{GPa}$ Fig. 6 and 7 for well ATG-10 and ATG11 respectively. And Track 8 is the calibrated failure parameters or rock strengths derived from compressional velocity logs which include: the internal friction angle $(\phi)$ from Plumb's correlation and ranges from $20.869^{\circ}$ to $65.5^{\circ}$ and $20.869^{\circ}$ to $45.61^{\circ}$, Unaxial compressive (UCS) strength which ranges from 757.837 psi to 2505.836 psi and 4577.099 psi to 10512.876 psi, cohesion Strength (C) which ranges from 205.697 psi to 355.308 psi and 70.652 psi to 390.32 psi and Tensile strength $\left(\mathrm{T}_{\mathrm{o}}\right.$ ) ranges from 17.141 psi to 29.609 psi and 5.885 psi to 32.527 psi for well ATG-10 and ATG-11 respectively. The elastic and rock strengths properties vary in a similar trend to the sonic logs as they are derived based on these values. These properties show increasing values with increasing depth, which is due to larger overburden, hence lower porosity or high compressional velocity of the formations. However, the elastic properties and formation strength may vary in different formations. 


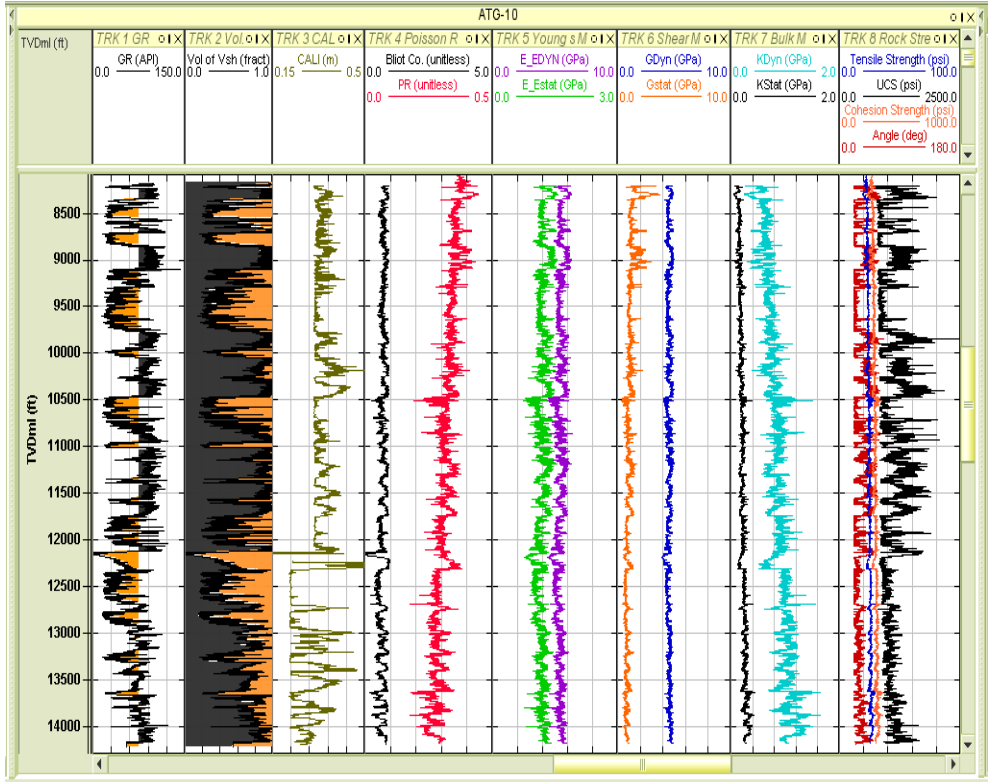

Fig. 8: Vertical Display of 1D MEM. Lithology Log (Track 1), Volumetric Fraction of Clay (Track 2) Caliper Log (Track 3) Poisson's Ratio and Biot's Coefficient (Track 4), Young's Modulus (Track 5) Shear Modulus (Track 6), Bulk Modulus (Track 7), and Rock Strengths (From Left to Right Panel) for ATG-10 Well.

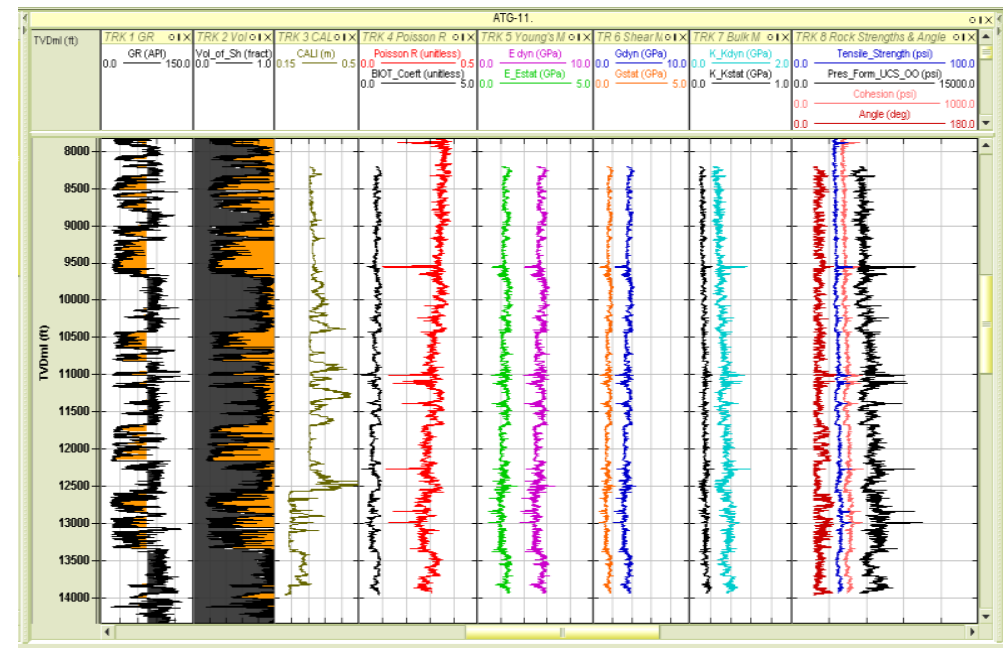

Fig. 9: Vertical Display of 1D MEM. Lithology Log (Track 1), Volumetric Fraction of Clay (Track 2) Caliper Log (Track 3) Poisson's Ratio and Biot's Coefficient (Track 4), Young's Modulus (Track 5), Shear Modulus (Track 6), Bulk Modulus (Track 7), and Rock Strengths (From Left to Right Panel) For ATG-11 Well.

The in situ stress magnitudes (Table 3 and 4) are displayed on the logs figure (10 and 11) for well ATG-10 and ATG-11 respectively. These vertical stress gradients indicates variation in the stress regime across the ATG-field with magnitudes ranging from $2.8 \mathrm{psi} / \mathrm{ft}$ at $3544.0 \mathrm{ft}$ to $3.1 \mathrm{psi} / \mathrm{ft}$ at $14224.50 \mathrm{ft}$ in ATG-10, and $2.3 \mathrm{psi} / \mathrm{ft}$ at $3912 \mathrm{ft}$ to $2.9 \mathrm{psi} / \mathrm{ft}$ at $14632.50 \mathrm{ft}$ in ATG-11. These vertical stress magnitudes indicates a continuous general increase with depth of burial (tables 3 and 4); this is due to increase in overburden stress which also corresponds to increase in fracture pressure and pore pressure gradients with depth of burial (tables 3 and 4). Pore pressure increase in ATG-10 and ATG-11 is reflecting the decrease in stress magnitudes. The magnitudes of the maximum $\left(\sigma_{\max }\right)$ and minimum horizontal stresses $\left(\sigma_{\max }\right)$ follow the trend of the vertical stress. Estimating the minimum horizontal stress in a well provides the lower limit of the fracture pressure and places a limit on the allowable injection pressure in all the two wells.

Therefore, the minimum horizontal stress magnitude of 9407.897psi, and the maximum horizontal stress magnitudes of 11317.43psi across ATG-10 and ATG-11 respectively may predict mud weight. The decrease in the stress magnitudes with depth of burial across the two wells is due to variations in the bulk densities of the oceanic crust across the shallow offshore of the delta. Variations in the oceanic rock densities across ATG-field could be as a result constant deposition silicilastic materials derived from the weathering of the onshore continental rocks during lifting and uplifting of the adjoining lower Benue trough in the late Jurassic to middle cretaceous (Lehner \& De Ruiter, 1977). Variations in vertical stress magnitude, pore pressure, fracture pressure may also account for the differences in the magnitudes of the horizontal stress elastic properties and densities of rocks across the basin.

Table 1: Rock Elastic Properties for Well Atg-10

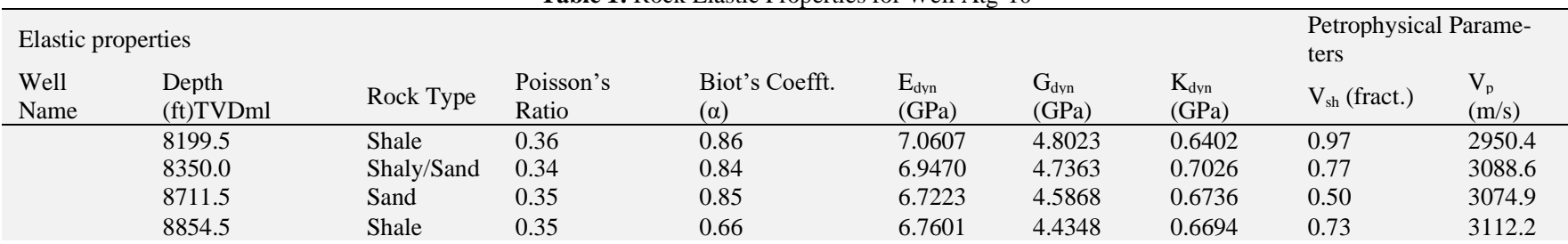




\begin{tabular}{|c|c|c|c|c|c|c|c|c|c|}
\hline \multirow{17}{*}{ ATG-10 } & 9118.5 & Sand & 0.34 & 0.75 & 6.4226 & 4.3207 & 0.6493 & 0.42 & 3106.3 \\
\hline & 9778.5 & Shaly/Sand & 0.34 & 0.64 & 6.5987 & 4.4488 & 0.6657 & 0.71 & 3100.3 \\
\hline & 9981.0 & Sand & 0.32 & 0.76 & 6.5987 & 4.4736 & 0.8083 & 0.49 & 3381.8 \\
\hline & 10052.5 & Shale & 0.34 & 0.57 & 7.0712 & 4.6976 & 0.7060 & 0.84 & 3106.8 \\
\hline & 10475.5 & Shale & 0.31 & 0.86 & 7.1833 & 4.7062 & 0.8627 & 0.96 & 3405.4 \\
\hline & 11021.0 & Shale & 0.28 & 0.58 & 7.1380 & 4.5017 & 0.9976 & 0.91 & 3748.0 \\
\hline & 11158.5 & Shale & 0.32 & 0.48 & 7.4372 & 4.8946 & 0.8183 & 0.76 & 3259.8 \\
\hline & 11348.0 & sand & 0.29 & 0.67 & 6.6706 & 4.3642 & 0.9197 & 0.50 & 3651.2 \\
\hline & 11400.5 & shale & 0.30 & 0.61 & 6.7405 & 4.3041 & 0.8643 & 0.73 & 3562.4 \\
\hline & 11620.5 & $\begin{array}{l}\text { Shaly } \\
\text { /sand }\end{array}$ & 0.28 & 0.63 & 7.2564 & 4.5506 & 1.0287 & 0.73 & 3787.5 \\
\hline & 11747.0 & Shaly/sand & 0.31 & 0.65 & 7.0690 & 4.6607 & 0.8970 & 0.62 & 3487.4 \\
\hline & 12131.0 & Sand & 0.33 & 0.82 & 7.1057 & 4.6694 & 0.7904 & 0.48 & 3278.6 \\
\hline & 12340.0 & Shaly/Sand & 0.28 & 0.58 & 6.9919 & 4.4167 & 0.9919 & 0.66 & 3774.4 \\
\hline & 13196.5 & Shaly/Sand & 0.30 & 0.84 & 7.1011 & 4.5700 & 0.9177 & 0.67 & 3562.3 \\
\hline & 13698.0 & Shaly/Sand & 0.25 & 0.58 & 7.3276 & 4.6326 & 1.2256 & 0.65 & 4129.1 \\
\hline & 14019.5 & Shale & 0.24 & 0.47 & 7.2017 & 4.4020 & 1.2105 & 0.72 & 4221.3 \\
\hline & 14189.0 & Sand & 0.29 & 0.84 & 7.5238 & 4.8656 & 1.0488 & 0.54 & 3694.1 \\
\hline
\end{tabular}

Table 2: Rock Elastic Properties for Well ATG-11

\begin{tabular}{|c|c|c|c|c|c|c|c|c|c|}
\hline \multicolumn{2}{|c|}{ Elastic properties } & \multirow[b]{2}{*}{ Rock Type } & \multirow[b]{2}{*}{$\begin{array}{l}\text { Poisson's } \\
\text { Ratio }\end{array}$} & \multirow[b]{2}{*}{$\begin{array}{l}\text { Biot's Coefft. } \\
(\alpha)\end{array}$} & \multirow[b]{2}{*}{$\begin{array}{l}E_{\text {dyn }} \\
(\mathrm{GPa})\end{array}$} & \multirow[b]{2}{*}{$\begin{array}{l}\mathrm{G}_{\text {dyn }} \\
(\mathrm{GPa})\end{array}$} & \multirow[b]{2}{*}{$\begin{array}{l}\mathrm{K}_{\mathrm{dyn}} \\
(\mathrm{GPa})\end{array}$} & \multicolumn{2}{|c|}{$\begin{array}{l}\text { Petrophysical Parame- } \\
\text { ters }\end{array}$} \\
\hline $\begin{array}{l}\text { Well } \\
\text { Name }\end{array}$ & $\begin{array}{l}\text { Depth } \\
\text { (ft)TVDml }\end{array}$ & & & & & & & $\mathrm{V}_{\text {sh }}$ (fract.) & $\mathrm{V}_{\mathrm{p}}(\mathrm{m} / \mathrm{s})$ \\
\hline \multirow{19}{*}{ ATG-11 } & 8201.0 & Sand & 0.36 & 0.7 & 5.1885 & 3.5416 & 0.466400 & 0.4 & 2933.5 \\
\hline & 8230.0 & shale & 0.35 & 0.7 & 5.4422 & 3.6801 & 0.535300 & 0.7 & 3060.2 \\
\hline & 8343.0 & sand & 0.30 & 0.6 & 5.2647 & 3.4241 & 0.699144 & 0.5 & 3590.1 \\
\hline & 9698.0 & shale & 0.33 & 0.7 & 5.4788 & 3.6618 & 0.596400 & 0.7 & 3218.5 \\
\hline & 10139.5 & Shaly/sand & 0.31 & 0.6 & 5.1723 & 3.4135 & 0.620930 & 0.6 & 3390.4 \\
\hline & 10430.5 & shale & 0.34 & 0.5 & 5.8782 & 3.9385 & 0.626878 & 0.7 & 3184.9 \\
\hline & 10831.5 & shale & 0.30 & 0.6 & 5.7192 & 3.7255 & 0.751907 & 0.8 & 3569.0 \\
\hline & 11012.0 & shale & 0.33 & 0.6 & 5.4054 & 3.5952 & 0.611742 & 0.7 & 3284.4 \\
\hline & 11100.0 & Shaly/sand & 0.28 & 0.5 & 5.6321 & 3.6065 & 0.823451 & 0.8 & 3805.2 \\
\hline & 11543.0 & shale & 0.31 & 0.7 & 5.4222 & 3.5552 & 0.681950 & 0.7 & 3479.4 \\
\hline & 11676.5 & Shaly/sand & 0.31 & 0.5 & 5.9268 & 3.8849 & 0.746913 & 0.6 & 3483.4 \\
\hline & 12156.5 & $\begin{array}{l}\text { Shaly } \\
\text { /sand }\end{array}$ & 0.27 & 0.6 & 5.5410 & 3.5429 & 0.817151 & 0.8 & 3825.8 \\
\hline & 12557.0 & Shaly/sand & 0.29 & 0.7 & 4.8679 & 3.1426 & 0.677693 & 0.6 & 3692.4 \\
\hline & 12870.0 & shale & 0.27 & 0.5 & 5.0122 & 3.1835 & 0.767565 & 0.7 & 3918.7 \\
\hline & 12914.0 & Shaly/sand & 0.28 & 0.8 & 4.6623 & 2.9850 & 0.682309 & 0.7 & 3807.4 \\
\hline & 13071.5 & shale & 0.25 & 0.5 & 4.7135 & 2.9683 & 0.755729 & 0.7 & 4038.2 \\
\hline & 13114.0 & sand & 0.25 & 0.7 & 5.0233 & 3.1413 & 0.834820 & 0.6 & 4136.8 \\
\hline & 13352.0 & sand & 0.25 & 0.5 & 4.8754 & 3.0654 & 0.788166 & 0.6 & 4060.4 \\
\hline & 13943.5 & shale & 0.30 & 0.8 & 5.8451 & 3.8212 & 0.750110 & 1.0 & 3519.6 \\
\hline
\end{tabular}

Results of figures 10 and 11 shows Mohr coulomb failure criterion (F) displayed on log curves (Track 3), with magnitudes ranging from -3473.33 psi to 7134.45 psi and -1816.41 psi with the corresponding lithology (Track 1), volumetric fraction of clay (volume of shale Track 2), rock strength (Track 4) and in-situ stress (Track 5), for ATG-10 and ATG-11 respectively. The numerical values for Mohr coulomb failure $(\mathrm{F})$ criterion are presented in tables 3 and 4 indicating zones compressional and shear failure, with minimum values of $3473.33 \mathrm{psi}$ at $13798.5 \mathrm{ft}$ and $-1816.42 \mathrm{psi}$ at $13714.5 \mathrm{ft}$ and maximum values of $7134.45 \mathrm{psi}$ at $9861.5 \mathrm{ft}$ and $4434.72 \mathrm{psi}$ at $11007.0 \mathrm{ft}$ for wells ATG-10 and ATG-11 respectively.

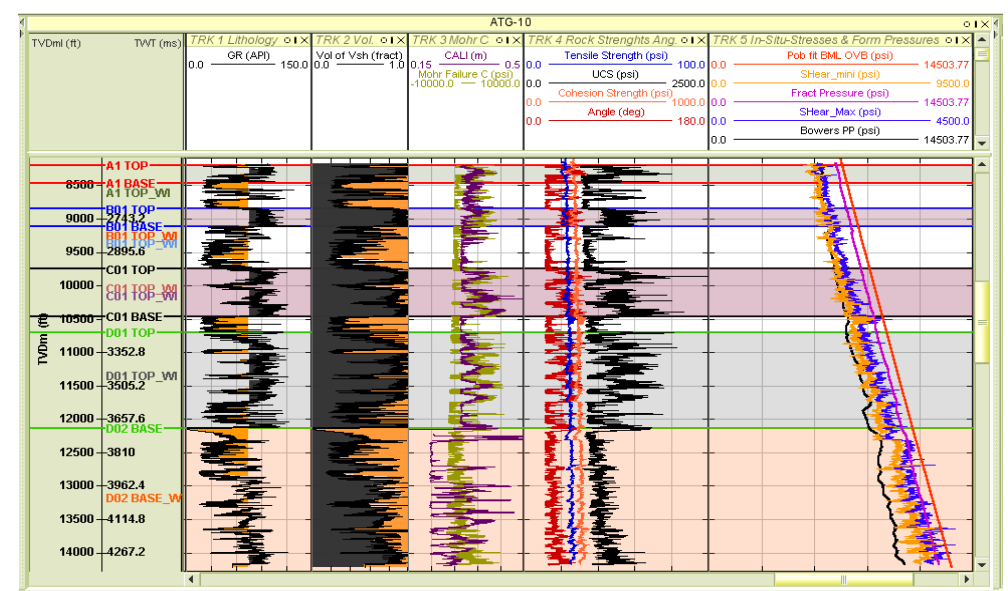

Fig. 10: Vertical Display of Failure Criterion (Mohr-Coulomb Failure). Gamma Ray (Lithology Log Track 1), Volumetric Fraction of Clay (Track 2), Mohr Coulomb and Caliper Log (Track 3), Failure Parameters (Track 4), in-Situ Stresses, Pore Pressure and Fracture Pressure (Track 5), for Well ATG10 . 


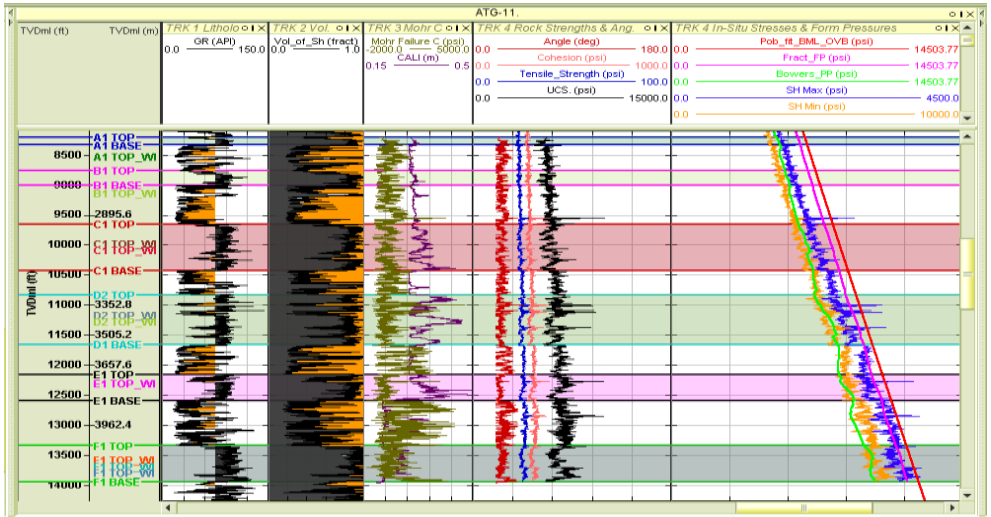

Fig. 11: Vertical Display of Failure Criterion (Mohr-Coulomb Failure). Gamma Ray (Lithology Log Track 1), Volumetric Fraction of Clay (Track 2), Mohr Coulomb and Caliper Log (Track 3), Failure Parameters (Track 4), and in-Situ Stresses, and in-Situ Stresses, Pore Pressure and Fracture Pressure (Track 5), for Well ATG-11.

Table 3: Rock Strength Failure Criterion and In-Situ Stress for well ATG-10

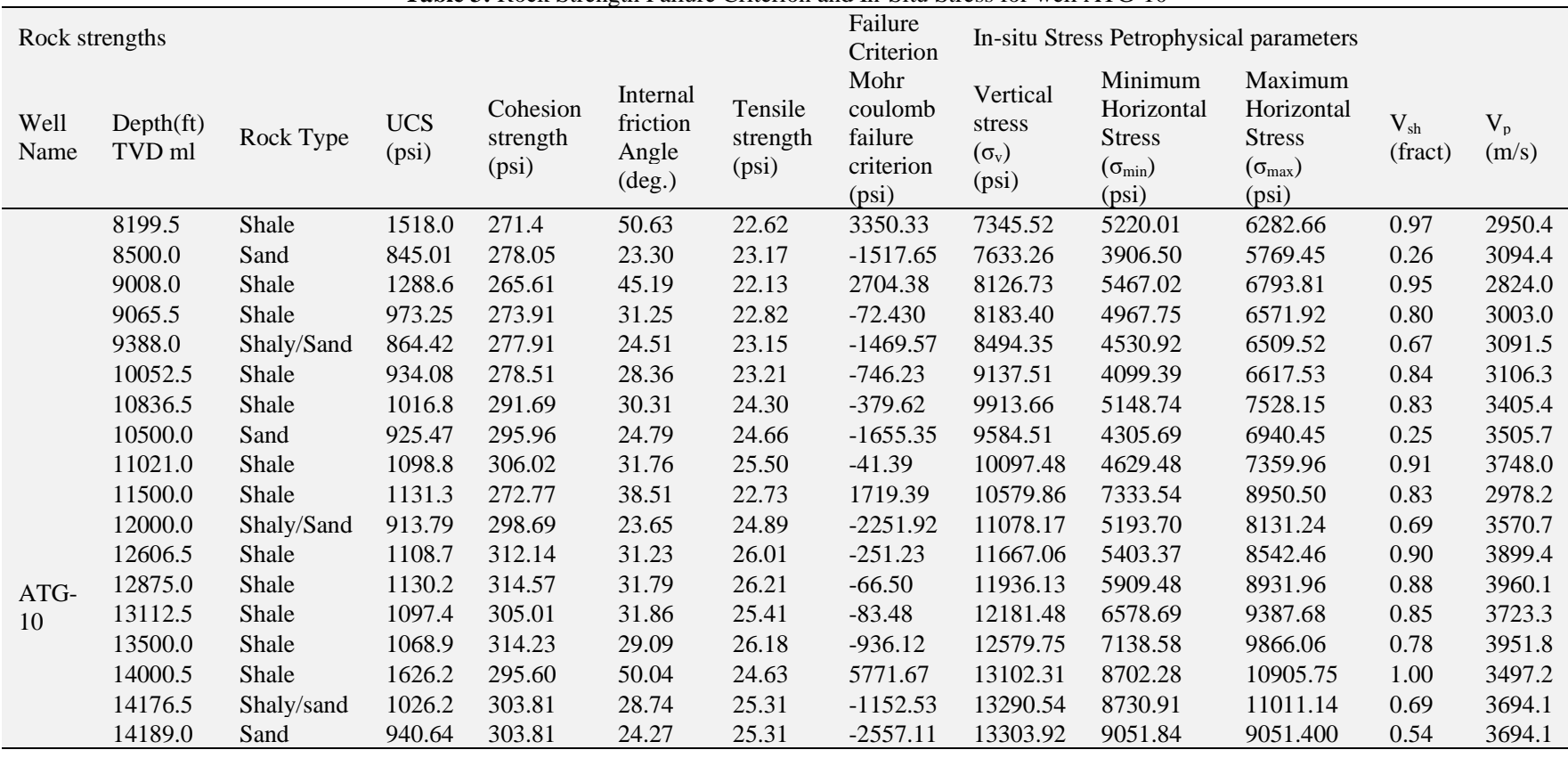

Table 4: Rock Strength Failure Criterion and in-Situ Stress for well ATG-11

\begin{tabular}{|c|c|c|c|c|c|c|c|c|c|c|c|c|}
\hline \multicolumn{7}{|c|}{ Rock strengths } & \multirow{2}{*}{$\begin{array}{l}\text { Failure } \\
\text { Criterion } \\
\text { Mohr } \\
\text { coulomb } \\
\text { failure } \\
\text { criterion } \\
\text { (psi) }\end{array}$} & \multicolumn{5}{|c|}{ In-situ Stress Petrophysical parameters } \\
\hline $\begin{array}{l}\text { Well } \\
\text { Name }\end{array}$ & $\begin{array}{l}\text { Depth(ft) } \\
\text { TVDml }\end{array}$ & Rock Type & $\begin{array}{l}\text { UCS } \\
\text { (psi) }\end{array}$ & $\begin{array}{l}\text { Cohesion } \\
\text { strength } \\
\text { (psi) }\end{array}$ & $\begin{array}{l}\text { Internal } \\
\text { friction } \\
\text { Angle } \\
\text { (deg.) }\end{array}$ & $\begin{array}{l}\text { Tensile } \\
\text { strength } \\
\text { (psi) }\end{array}$ & & $\begin{array}{l}\text { Vertical } \\
\text { stress } \\
\left(\sigma_{\mathrm{v}}\right) \\
(\mathrm{psi})\end{array}$ & $\begin{array}{l}\text { Minimum } \\
\text { Horizontal } \\
\text { Stress } \\
\left(\sigma_{\min }\right) \\
(\mathrm{psi})\end{array}$ & $\begin{array}{l}\text { Maximum } \\
\text { Horizontal } \\
\text { Stress } \\
\left(\sigma_{\max }\right) \\
(\mathrm{psi})\end{array}$ & $\begin{array}{l}\mathrm{V}_{\text {sh }} \\
\text { (fract) }\end{array}$ & $\begin{array}{l}\mathrm{V}_{\mathrm{p}} \\
(\mathrm{m} / \mathrm{s})\end{array}$ \\
\hline \multirow{17}{*}{$\begin{array}{l}\text { ATG- } \\
11\end{array}$} & 8201.0 & Sand & 5407.6 & 270.72 & 22.81 & 22.56 & -882.068 & 6648.33 & 2819.21 & 6143.37 & 0.4 & 2933.5 \\
\hline & 8230.0 & Shale & 5706.5 & 276.50 & 21.18 & 23.04 & -1013.81 & 6674.81 & 3136.09 & 6473.81 & 0.7 & 3060.2 \\
\hline & 9698.0 & Shale & 6010.6 & 283.57 & 20.96 & 23.63 & -1204.25 & 8083.22 & 3481.85 & 7523.47 & 0.7 & 3218.5 \\
\hline & 10139.5 & Shaly/sand & 6335.6 & 291.05 & 20.86 & 24.25 & -1126.53 & 8529.38 & 3604.13 & 7868.82 & 0.6 & 3390.4 \\
\hline & 10442.0 & Sand & 6091.9 & 299.85 & 32.16 & 24.98 & 1027.04 & 8830.83 & 2863.38 & 7278.79 & 0.2 & 3598.5 \\
\hline & 10460.5 & sand & 5736.0 & 292.35 & 33.02 & 24.36 & 1073.39 & 8848.27 & 2792.99 & 7217.13 & 0.2 & 3420.8 \\
\hline & 10831.5 & Shale & 6514.6 & 295.18 & 20.92 & 24.59 & -1253.91 & 9206.93 & 3235.30 & 7838.77 & 0.8 & 3569.0 \\
\hline & 10995.0 & sand & 5719.2 & 295.35 & 35.00 & 24.61 & 1584.36 & 9373.40 & 1741.53 & 6428.23 & 0.2 & 3491.4 \\
\hline & 11012.0 & Shale & 6098.1 & 285.54 & 20.87 & 23.79 & -1404.41 & 9390.85 & 3125.80 & 7821.23 & 0.7 & 3284.4 \\
\hline & 11669.5 & Shaly/Sand & 5533.0 & 276.92 & 25.66 & 23.07 & -645.463 & 10049.37 & 6920.98 & 11945.67 & 0.7 & 3069.4 \\
\hline & 12557.5 & Shaly/Sand & 7642.0 & 319.87 & 21.06 & 26.65 & -722.57 & 10928.98 & 5784.83 & 11249.32 & 0.5 & 4094.7 \\
\hline & 12882.0 & Shale & 7785.0 & 326.33 & 24.01 & 27.19 & -135.46 & 11245.32 & 5647.16 & 11269.82 & 0.9 & 4261.6 \\
\hline & 13075.0 & shale & 7542.0 & 319.73 & 22.81 & 26.64 & -508.20 & 11435.29 & 3744.10 & 9461.75 & 1.0 & 4091.2 \\
\hline & 13114.0 & sand & 5911.8 & 298.77 & 34.16 & 24.89 & 1765.52 & 11500.82 & 2905.56 & 8655.97 & 0.6 & 4136.8 \\
\hline & 13943.0 & shale & 5887.7 & 296.54 & 33.22 & 24.71 & 1581.79 & 12316.56 & 7378.29 & 13536.57 & 1.0 & 3519.6 \\
\hline & 12882.0 & Shale & 7785.0 & 326.33 & 24.01 & 27.19 & -135.46 & 11245.32 & 5647.16 & 11269.82 & 0.9 & 4261.6 \\
\hline & 13943.5 & shale & 5839.2 & 296.54 & 33.94 & 24.71 & ND & $\mathrm{ND}$ & ND & ND & 1.0 & 3519.6 \\
\hline
\end{tabular}




\section{Conclusions}

Geomechanical characterization was carried out using two wells ATG 10 and ATG-11 from ATG-field offshore Niger. This is to develop mechanical earth model to predict, wellbore instability and determine the state of in situ stress. Petrophysical properties such as gamma ray, density, porosity, shale volume and Vp and Vs were derived from wire logs data. Mechanical Earth Model (MEM) based on elastic parameters, failure parameters, in-situ stresses, pore pressure using empirical relationship to predict wellbore failure. Formation pore pressure was estimated from the Bower's model, and Poisson's ratios derived from compressional and shear velocities interval transit time and density logs (RHOB), elastic parameters, rock strengths derived from compressional velocity logs vary in a similar trend to the sonic logs as they were derived based on these values. These properties show increasing values with increasing depth, which is due to large overburden stress, hence lower porosity or high compressional velocity of the formations. However, the elastic properties and formation strength may vary in different formations. Then, the magnitude of $S_{\mathrm{H}}$ and $\mathrm{S}_{\mathrm{h}}$ were determined using the poro-elastic formulations. Mohr coulomb failure $(F)$ criterion indicating zones compressional and shear failure, with minimum at $13798.5 \mathrm{ft}$ and at $13714.5 \mathrm{ft}$ for wells ATG-10 and ATG-11 respectively. There was decrease in the stress magnitudes with depth of burial across the two wells (ATG-10 and ATG-11), and this is attributed due to variations in the bulk densities of the oceanic crust across the shallow offshore of the delta and also variations in the pore pressure and disequilibrium compaction and low porosities. Variations in the oceanic rock densities across ATG-field could be as a result constant deposition silicilastic materials derived from the weathering of the onshore continental rocks during lifting and uplifting of the adjoining lower Benue trough in the late Jurassic to middle cretaceous (Lehner \& De Ruiter, 1977). Variations in vertical stress magnitude, pore pressure, fracture pressure may also account for the differences in the magnitudes of the horizontal stress.

\section{References}

[1] Aadnøy, B. S. (2003). Introduction to special issue on wellbore stability. Journal of Petroleum Science and Engineering. 38:79-82. https://doi.org/10.1016/S0920-4105(03)00022-6.

[2] Aadnoy, B., \& Looyeh, R. (2011). Petroleum rock mechanics: drilling operations and well design. Gulf Professional Publishing, Stavanger, Norway: Elseviewer. p376.

[3] Bell, D. W. (2002). Velocity estimation for pore-pressure prediction: In Huffman A. R. \& Bowers, G. L. eds., Pressure regimes in sedimentary basins and their prediction: $A A P G$ Memoir 76, 177 -215. https://doi.org/10.1306/M76870C18.

[4] Bowers, G.L. (1995). Pore pressure estimation from velocity data: accounting for overpressure mechanisms besides under compaction. SPE Drill. Complet. 10(02), 89-95. https://doi.org/10.2118/27488-PA.

[5] Bozorgi, E., Javani., D. \& Rastegarnia, M. (2016). Development of a mechanical earth model in an Iranian off-shore gas field Islamic Azad University, Science and Research Campus, Tehran, Iran Imam Khomeini International University, Ghazvin, Iran School of Mining, Petroleum \& Geophysics Engineering, Shahrood University of Technology, Shahrood.37-46. Iran Journal of Mining \& Environment, 7(1), 2016. DOI: 10.22044/jme.2016.457.

[6] Cheng, X., Tan, C.P., \& Detournay, C. (2003). A Study on Wellbore Stability in Fractured rock masses with impact of mud infiltration. Journal of Petroleum Science and Engineering, 38(3/4) 145-154. https://doi.org/10.1016/S0920-4105(03)00028-7.

[7] Corredor, A., Lessenger, M.A., \&. Capentino, P. (2005). Comparative source rock evaluation of opuama channel complex and adjacent producing areas of Niger Delta, Am. Assoc. Pet. Geol. Bull. 2(6), 10-27.

[8] Denney, D. (2011). 3D geomechanical modeling of optimizes drilling in the Llanos orientales basin Columbia. Journal of Petroleum technology, 63 (9) 86-88 https://doi.org/10.2118/0911-0086-JPT.

[9] Doust, H, \& Omatsola, E. (1990). Divergent/passive Margin Basins. AAPG Memoir 48, 239-248.

[10] Doust, H. Omatsola E., (1990). Niger Delta. In Edwards, J.D. Santogrossi P.A. (1990). Divergent/passive Margin Basins, (Eds.). AAPG Memoir 48, American Association of Petroleum Geologists, Tulsa. 239-248.

[11] Frankl, E.J. \& Cordry, E.A. (1967). The Niger Delta oil province-recent developments onshore and offshore. Seventh World Petroleum Congress, Proceedings, Mexico City, Mexico, 1B, 195-209.

[12] Islam, M. A., Skalle, P., Al-Ajmi, A. M. \& Soreide, O. K. (2010). Stability analysis in shale through deviated boreholes using the Mohr and MogiCoulomb failure criteria: ARMA. 10-432.

[13] Iqbal, O., Ahmad, M., \& Abd Kadir, A., P. A, (2017). Geomechanical Characterization of Potential Roseneath Shale Gas, Cooper Basin, Australia. Asian Research Publishing Network (ARPN, Journal of Engineering and Applied Sciences. 12(17),1-11.

[14] Jaeger, J. C., Cook, N. G, \& Zimmerman, R. W. (2007). Fundamentals of rock mechanics. U.S.A: Blackwell Publishing.

[15] Kaplan, A., Lusser, C.U, Norton, I.O. (1994). Tectonic map of the world, panel 10: Tulsa. Am. Ass Petro Geol, scale.

[16] Kidambi, T \& Kumar, G.S. (2016). Mechanical Earth Modeling for a vertical well drilled in a naturally fractured tight carbonate gas reservoir in the Persian Gulf. Journal of Petroleum Science Eng. 141:38-51. https://doi.org/10.1016/j.petrol.2016.01.003.

[17] Klett, T.R., Ahlbrandt, T.S., Schmoker, J.W., \& Dolton, J.L. (1997). Ranking of the world's oil and gas provinces by known petroleum volumes. US Geological Survey Open-file Report-97-463, CD-ROM. https://doi.org/10.3133/ofr97463.

[18] Kulke, H., (1995). Nigeria. In, Kulke, H., ed., Regional Petroleum Geology of the World. Part II: Africa, America, Australia and Antarctica: Berlin, Gebrüder Borntraeger, p. 143-172.

[19] Lambert-Aikhionbare, D.O. \& Ibe, A.C. (1984). Petroleum source-bed evaluation of the Tertiary Niger Delta: Discussion. AAPG Bulletin, 68: $387-$ 394. https://doi.org/10.1306/AD460A2B-16F7-11D7-8645000102C1865D.

[20] Lehner, P., De Ruiter, P.A.C. (1977). Structural history of Atlantic margin of Africa. American association of petroleum Geologists bulletin, 61, pp 961-981 https://doi.org/10.1306/C1EA43B0-16C9-11D7-8645000102C1865D.

[21] Lianyang Zhang, \& Radha., P. C. (2010). Evaluation of rock strength criteria for wellbore stability analysis." International Journal of Rock Mechanics and Mining Sciences 47(8), 1304-1316. https://doi.org/10.1016/j.ijrmms.2010.09.001.

[22] Luo, G., Nikolinakou, M. A., Flemings, P. B., \& Hudec, M. R. (2012). Geomechanical modeling of stresses adjacent to salt bodies: Part 1Uncoupled models. AAPG Bulletin, 96(1), 43-64. https://doi.org/10.1306/04111110144.

[23] Moos, D., Peska, P., Finkbeiner, T., \& Zoback, M.D., (2003). Comprehensive wellbore stability analysis utilizing quantitative risk assessment. In Chang, C., Mark D. Zoback, M.D., \& Khaksar, A (2006). Empirical relations between rock strength and physical properties in sedimentary rocks Department of Geophysics, Stanford University, Palo Alto, CA 94305-2215, USA GeoMechanics International, Inc., Perth, WA 6000, Australia.

[24] Plumb, R.A., (1994). Influence of composition and texture on the failure properties of clastic rocks. Eurock 94, Rock Mechanics in Petroleum Engineering conference, Delft, Netherlands, pp 13-20. https://doi.org/10.2118/28022-MS.

[25] Plumb, R., Edwards, S., Pidcock, G., Lee, D., \& Stacey, B. (2000). The mechanical earth model concept and its application to high-risk well construction projects. In IADC/SPE Drilling Conference. Society of Petroleum Engineers. https://doi.org/10.2118/59128-MS.

[26] Short, K.C., \& Staublee, A.J. (1965). Outline of Geology of Niger Delta. Am. Ass. Petrol Geol Bull. 51, 761-779.

[27] The Leading Eadge (May 2007). Geomechanics. Society of exploration geophysics (SEG) ISSN1070-485, (5), 6.

[28] Tuttle, M.L.W., Charpentier, R.R., \& Brownfield, M.E. (1999). The Niger Delta petroleum system: Niger Delta Province, Nigeria, Cameroon, and Equatorial Guinea, Africa. USGS, Open-File Report 99-50-H. https://doi.org/10.3133/ofr9950H. 
[29] Wang, Z. (2000). Dynamic versus static elastic properties of reservoir rocks. Seismic and Acoustic Velocities in Reservoir Rocks, SEG Geophysics Reprint Series, 19.

[30] Weber, K.J., \& Daukoru, E.M. (1975). Petroleum geology of the Niger Delta. Proceedings of the Ninth World Petroleum Congress, volume 2, Geology: London, Applied Science Publishers, Ltd., 209-221.

[31] Zoback, M.D., Barton, C.A., Brudy, M., Castillo, D.A., Finkbeiner, T., Grollimund, B.R., Moos, D.B., Peska, P., Ward, C.D., Wiprut, D.J. (2003). Determination of stress orientation and magnitude in deep wells. Int. J. Rock Mech. Min. Sci. 40:1049-1076. https://doi.org/10.1016/j.ijrmms.2003.07.001. 